\title{
Effects of Students and School Variables on SBS Achievements and Growth in Mathematic*
}

\author{
Emine YAVUZ **
}

Şeref TAN ***

Hakan Yavuz ATAR ****

\begin{abstract}
The purpose of this study is to investigate the effects of several student and school level variables on students' mathematical achievement and mathematical achievement growth in middle school. The research population consisted of students in Ankara who started middle school in 2008 and graduated in 2011. Using a non-random typical case sampling method, 3715 students were sampled from 40 middle schools. The data used in this study were obtained from the Ministry of National Education with express written permission. Student Placement raw mathematics subtest scores from 2009 to 2011 were used as the dependent variable in the analysis. "Gender, mathematics grade point average in $6^{\text {th }}$ grade, and school attendance at sixth grade" comprised the student level variables whereas "school type and school size" variables comprised the school-level variables. A three-level hierarchical linear growth model was used to investigate the effects of these variables. Students' raw mathematics subtest scores in Students Placement Test were included in the model after these scores were equated. The results of the model analysis indicated that there was no growth in students' mathematical achievement. It was also observed that school attendance, sixth-grade mathematics grade point average and school type had a statistically significant effect on students' sixth-grade mathematical achievement.
\end{abstract}

Key Words: Mathematical Achievement, Mathematical Achievement Growth, Three-Level Hierarchical Linear Model, Growth Model, Equipercentile Method

\section{INTRODUCTION}

Mathematical achievement and mathematical achievement growth in middle school have an effect on future performance and career of students. Various factors (such as variables related to school and students' own backgrounds, past achievement, gender, parental education, etc.) are sources of information for students' future achievements. This study is aimed at examining the students' mathematical achievement growth as well as the effects of student and school characteristics on the achievement of students in the Student Placement Test (SBS) mathematical. SBS is a test put into practice by the Ministry of National Education (MoNE) in 2007 for the follow-up and evaluation of students' mathematical achievement growth. MoNE carried out the process from the preparation of the SBS questions to the application of the examination and scoring. MoNE prepares a common guideline for the collection of data in similar environments and with a similar system. The guideline is handed over to the examiners, and it is tried to avoid bias arising from the differences between the examiners and their environment. The validity and reliability studies of the data obtained from the exam are done by the respective experts in the MoNE (Milli Eğitim Bakanlığı, 2011).

There are studies in the literature on the use of national like SBS and international (The Programme for International Student Assessment - PISA and The Trends in International Mathematics and

\footnotetext{
*This study was derived from master's thesis named "Effects of Students and School Variables on SBS Achievements and Growth in Mathematic: An Investigation with Three-Level Hierarchical Linear Growth Model" completed on 26.10.2015 under the guidance of Prof. Dr. Şeref TAN.

** Research assisstant, Erciyes Üniversity, Ziya Eren Faculty of Education, Kayseri-Turkey, yavuzemine0@gmail.com ORCID ID: 0000-0002-1991-1416

*** Professor, Gazi University, Gazi Faculty of Education, Ankara-Turkey, sereftan4@yahoo.com ORCID ID: 0000-00029892-3369

**** Associate Professor, Gazi University, Gazi Faculty of Education, Ankara-Turkey, hakanyavuzatar@gmail.com ORCID ID: $\underline{0000-0001-5372-1926}$
}

To cite this article:

Yavuz, E., Tan, Ş., \& Atar, H., Y. (2019). Effects of students and school variables on SBS achievements and growth in mathematic. Journal of Measurement and Evaluation in Education and Psychology, 10(1), 96-116. DOI: 10.21031/epod.493297 
Science Study - TIMSS) test data applied to large samples in determining student and school variables that affect mathematical achievement (Altun, 2007; Karabay, 2012; Ötken, 2012; Özdemir, 2010; Reçber, 2011; Savaşç1, 2011 \& Y1lmaz, 2006). Multiple regression analysis was used to answer research questions without taking the sample structure into consideration in most of these studies. PISA, TIMSS, ÖBBS and SBS data are obtained from large samples, and these data often have multilevel structures. Students, for instances, are nested in classrooms, classrooms in schools and so forth. Students in the same class or school in this data structure show more similar characteristics to each other than students who are selected at random from the class. For this reason, it cannot be said that the observations obtained from the individuals in the same social unit are completely independent of each other (Raudenbush \& Bryk, 2002). Furthermore, some schools are more homogeneous based on certain features (e.g., socioeconomic status, region, etc.) while others are heterogeneous. This means that the assumption of equality of variances is not achieved in large samples (Hox, 2010, pp. 4-7; Raudenbush \& Bryk, 2002). Also, for this reason, the assumption of independence of observations and homogeneity of variances is not achieved. In addition, multiple regression analysis can yield biased results since multilevel data structures are not considered in large sample trials (Raudenbush \& Bryk, 2002, pp. 5-99).

Another method of analysis used in the literature to study the effect of student and school variables on mathematical achievement is the ordinary least squares (OLS, linear least squares) method. However, according to the relevant literature, the OLS regression methods underestimate standard errors compared to the multilevel model (Hox, 2010). Underestimation of standard errors increases the probability of Type I error in the estimation of regression parameters, which is not desirable (Hox, 2010). Furthermore, the OLS regression poses a problem in interpretation, such as bias of aggregating the individual-level variables to the higher level and the determination of heterogeneity between schools (Raudenbush \& Bryk, 2002, p. 253). As indicated above, multiple regression and OLS methods yield biased results due to aggregation bias, underestimation of standard errors, and regression heterogeneity (Bryk \& Raudenbush, 1988). To avoid these biased results, multilevel analysis models should be used to analyze the data from multilevel samples (Atar, 2010; Atar \& Atar, 2012; Demir \& K1lıç, 2010; Güzel, 2006; Sevgi, 2009). In essence, multilevel models are generalized regression methods and can be used for causal interpretation, data reduction, and various estimation purposes (Hox, 2010).

This study is aimed at examining the students' mathematical achievement growth and the effects of student and school characteristics on students' SBS mathematical achievement. Growth in the study refers to the change in the SBS mathematics scores of the students that they received over the years. Based on the fact that the data structure is multilevel, three-level hierarchical linear growth model was used in this study to avoid the bias of single-level analysis methods for this data. In light of this, level-1 consists of a repeated measure of students' SBS mathematics scores, level-2 consists of students' characteristics variables and finally level-3 consists of school characteristics variables. After a thorough review of Turkish literature, no study was found examining the factors that affect mathematical achievement and mathematical achievement growth by a three-level hierarchical model. However, there are many studies using three-level hierarchical linear growth models abroad (Ding, Song \& Richardson, 2010; Huang et al., 2009; Raymond, 2009; Shapley et al., 2011; Shim, 1995; Wu, 2004; Yang, 2000; Zhu, 1998). In addition, when the literature was examined, there were many studies examining student, school and country variables as they affect the mathematical achievement abroad with three-level hierarchical linear model (HLM) (Agodini \& Harris, 2016; Kao et al., 2017; Tan \& Hewer, 2018; Yi \& Shin, 2018). It was found that only two studies in Turkey (Aztekin \& Y1lmaz, 2014; Çelik, 2016) were found to be relevant. Çelik (2016), only the studies the effects of the variables of country while Aztekin and Yilmaz (2014) examined the effects of variables of students, schools, and countries. In addition, the effect of some variables in PISA and TIMSS mathematical achievement was examined in these two studies. Unlike the international large scale exams that reflect international committees' goal and objectives, SBS reflects the goals and objectives of the Turkish education system. This study is important because it examines students' mathematical achievement growth in SBS and the effects of some student and school variables on 
SBS mathematical achievement in the middle school in the Turkish education system. Studies conducted in Turkey mostly examine the effect of variables such as gender, school attendance and teacher qualifications on mathematical achievement using one or two level models. Although there seems to be a growing interest in the use of three-level models in the analysis of multilevel data in the Turkish literature, they are still too few to draw valid conclusions (Çelik, 2016). It is thought that this study will be an example of a three-level hierarchical growth model implications in Turkish literature.

\section{Purpose of the Study}

The purpose of this study is to investigate the effects of several student-level variables (gender, grade point average and school attendance in sixth grade) and school-level variables (school type and school size) on students' mathematical achievement and mathematical achievement growth in middle school using three-level hierarchical linear growth model. For this purpose, the following research questions were investigated:

1) Do the sixth-grade students' SBS mathematical achievements vary at the student level and school level? If yes, what percentage of variance is accounted for at each level?

2) Is there any growth in students' SBS mathematics raw scores in middle school from 2009 to 2011 ?

3) Do the sixth-grade students' SBS mathematical achievements vary according to student-level variables (Gender, grade point average in sixth grade-GPA6 and attendance at school in sixth gradeABSENTEEISM)? If yes, what percentage of variance is accounted for the student-level variables?

4) Do the sixth-grade students' SBS mathematical achievements vary according to school-level variables (school size and type)? If yes, what percentage of variance is accounted for by the studentlevel variables?

\section{METHOD}

This research is a causal comparison model of quantitative research methods (Büyüköztürk, et al., 2008) as it examines the effects of variables related with students and schools on students' mathematical achievement and mathematical achievement growth in middle schools.

\section{Sample}

The research population consisted of students in Ankara who started middle school in 2008 and graduated in 2011. One of the aims of this study is to get detailed information about the universe by choosing a typical situation which is thought to represent the universe. Therefore, a typical sampling method (Büyüköztürk et al. 2008, p. 91) was used to determine a sample of middle schools in the province of Ankara and the research was conducted on the data of these schools. The data used in the study were obtained as a result of correspondence with the Ministry of National Education (MONE). So, 40 schools from the middle school universe in Ankara and 3733 students who were educated in these schools were randomly assigned in the years related to codes created by the Ministry of National Education. While the school sample consists of 39 public schools and 1 private school, a worthy observation made is that the average number of these schools in the relevant years varies between 12 and 255. The existence of one private school in the sample shows the limitation of the research in terms of school diversity. The research sample was first composed of 3733 students. However, it was decided that the outliers of the data - 18 students - should not be included in the analysis because the sample was large enough. The research sample takes its final form as 3715 students in 40 middle schools in Ankara who started in middle school in 2008 and graduated in 2011. It has been taken into consideration that the students who are in the sample group should not have changed school during their education. The research sample is suitable for HLM analysis because at 
least two repetitive measurements are used for the study of change, and students (3715 persons) are placed at the second level, and the number of units in the third level is left to the researcher's ability to reach the database.

\section{Data Collection Instrument}

The aim of the study was to examine the variables affecting the achievement of the students and the changes in their achievement. Repeated measures are needed to examine the students' achievement growth. In the Turkish education system, these repeated measures were first obtained with SBS, and it is thought that there will be similar exam applications for follow-up examinations. In this study, raw mathematics scores obtained from the students' SBS were used to examine mathematical achievement. These raw scores were included in the analysis as dependent variables.

\section{Level-1 variables (Dependent variable)}

The sixth, seventh and eighth grade SBS mathematic subtest data belonging to the same students are raw scores. The raw scores are calculated by applying correction formula to the number of items answered correctly. They were included as a continuous variable in the HLM analysis and considered as dependent variables. The aim is to determine the change or students' achievement growth by examining these points together.

\section{Level-2 variables (Student level variables)}

Gender (GENDER), absenteeism (ABSENTEEISM6) and year-end mathematics grade point averages of students for the 2008-2009 academic year (GPA6).

Year-end mathematics grade point averages are based on the average grade that the students took in two semesters in mathematics lessons in related years and included as a continuous variable in this study. Gender is a dummy variable; male students are coded as " 0 " and female students are coded as "1". The absenteeism is the number of days during which the students did not come to school in the related education years. It was regarded as a continuous variable. While gender is a constant variable that does not change over time, the absenteeism and year-end mathematics grade point averages of students are the variables that change over time (year to year). Since the aim is to examine the effects of the initial state (grade point average in $6^{\text {th }}$ grade) of students on mathematical achievement and mathematical achievement growth in this study, time-varying variables (year-end absences and yearto-year mathematics grade point averages) are included as fixed variables.

\section{Level-3 variables (School level variables)}

School size (SIZE) and type (TYPE) variables are included as third level variables in the analysis. School size refers to the average number of students per school, and it has been considered as a continuous variable. School type is a dummy variable in which public schools are coded as "0" and private schools are coded as "1".

\section{Data Analysis}

\section{Providing equivalency of SBS scores: Equipercentile method}

In order to determine the students' mathematical achievements growth, it is necessary to monitor their mathematical achievements over the years. For this purpose, it is necessary to compare the SBS mathematics subtest scores of the students. The procedures for comparing student achievements are insufficient because of the differences in the number of items used in SBS exams, their reliabilities, 
and difficulties. For this reason, it is necessary to convert test scores to the same score scale before including SBS raw scores in the HLM analysis. Middle mathematics curriculum has a helical structure (Ersoy, 2006) and the contents of SBS mathematics subtests are compatible with the curriculum of the related years (MEB, 2011); therefore, the structure of SBS mathematics subtests was thought to be similar and the test scores equated before the HLM analysis. Equivalence of SBS scores in this study is provided by equipercentile equation method.

The reliability of the test scores must be high in order to use equipercentile method (Schneider \& Dorans, 1999). The reliability coefficients of KR-21 for the sixth, seventh and eighth grade SBS raw scores used in the study were $0.86 ; 0.90$ and 0.92 , respectively. Thus, the high reliability of the raw scores is enough to do the equation study.

The extreme values in the data set consisting of 3733 students were determined before the equipercentile method was started. So, the $\mathrm{Z}$ scores of the SBS raw scores were calculated, and the scores (18 students) belonging to the students who were out of the range of \pm 4 were discarded from the data set (Çokluk, Şekercioğlu \& Büyüköztürk, 2014, p. 14). In addition, missing values were taken as "0". Raw scores are calculated by applying correction formula to the number of items answered correctly. Scaled scores were analyzed in the Rage3.15 program. Since the sample is not very large and the four moments of the forms are not very close to each other as a result of the equipercentile method, smoothing was done. Then, beta4 value and chi-square difference values were examined and it was decided to perform polynomial pre-smoothing at $\mathrm{C}=4$. Smoothed equivalent scores were used in the HLM analysis.

\section{HLM analysis: Three-level hierarchical linear growth models}

Hierarchical linear models are the generalization of the regression methods used for various purposes such as causal interpretations, various estimates, and data reduction (Raudenbush \& Bryk 2002). HLM7 software was used for conducting HLM analysis in this study. This analysis starts with a completely unconditional model, then continues with a base model where level-1 is simple linear growth. Finally, intercept and slope of level-1 becomes dependent variables at level-2 and level-3. There was not any growth in this analysis; the only intercept of level-1 becomes dependent variables at level-2 and level-3. In addition, student variables are added to the base model to answer research question three and variables related to school are added to the base model to answer research question four.

Completely unconditional model: As the name implies, there are no explanatory variables in the model except for the intercept coefficients. This model provides a basis for the definition of the level-1 model and useful evidence for the development of basic statistics for the evaluation of other models (Heck and Thomas, 2009, p. 173). In addition, this model used for checking the proportion of total variance in the outcome can be explained by group membership (e.g., with ICC). The model equation is:

Level-1: $\quad \mathrm{Y}_{t i j}=\pi_{0 i j}+e_{t i j}$

Level-2: $\quad \pi_{0 i j}=\beta_{00 j}+r_{0 i j}$

Level-3: $\quad \beta_{00 j}=\gamma_{000}+u_{00 j}$

Combining model: $Y_{t i j}=\gamma_{000}+u_{00 j}+r_{0 i j}+e_{t i j}$

In this study, the subscripts which are t, i, j represent time (test taking year: 2009, 2010, 2011), student and school, respectively.

$Y_{t i j}$ : SBS mathematics score at $t$ time of student-i in school-j.

$\pi_{0 i j}$ : The intercept coefficient indicating the estimated initial state (mathematical achievement in the sixth grade) of the student-i in school-j

$\beta_{00 j}$ : mean score of SBS mathematics scores of students in the sixth grade in school-j

ISSN: 1309 - 6575 Eğitimde ve Psikolojide Ölçme ve Değerlendirme Dergisi

Journal of Measurement and Evaluation in Education and Psychology 
$\gamma_{000}$ : The general mean of mathematics score (general average) for all students in the 2009 SBS (sixth grade SBS)

$e_{t i j}$ : Effect of repeated measurements at $t$ time, first order random effect. Errors are independent and normally distributed. The mean is " 0 " and the constant variances are $\sigma^{2}$ (Raudenbush \& Bryk, 2002, p. 162).

$r_{0 i j}$ : Second-level intercept $\left(\beta_{00 j}\right)$ effect. So the difference between mathematics score of student-i and the school-j 's average mathematics score, the deviation amount. The mean is " 0 " and variance is $\tau_{\pi}$.

$u_{00 j}$ : Third-level intercept effect. The difference between the average mathematics score of the school-j and the general mathematics score is the amount of deviation. In other words, it is the unexplained difference in the average mathematics scores of schools. The mean is " 0 " and the variance is $\tau_{\beta}$.

Level-1 model (Unconditional model for growth): The level-1 model was used to answer the second research question. In the demonstration of individual growth in the HLM, more polynomial curves are used because they are flexible and predict standard linear modeling procedures. Since there were three repeated measurements belonging to the students in this study, linear development model was used in the analysis of the data.

In the study, "class" (encoded as $0,1,2$ ) was chosen as the time unit. The time points in the measurement (the time periods during which the exams were applied) are the $6^{\text {th }}$ grade (time $\left.=0\right), 7^{\text {th }}$ grade (time $=1)$ and $8^{\text {th }}$ grade $($ time $=2)$. For this reason, the intercept parameter $\left(\pi_{0 i j}\right)$ interpreted as the actual starting status at time point $a_{i t}=0$ of the student $i$. The time point $a_{i t}=0$ is the sixth grade SBS. Interpretation of the intercept as the real starting point forms the basis for interpreting the development of the students in the sample over time. The slope is interpreted as the annual rate of change of mathematical achievements of students, which is represented by the growth curves and is formed by time effect. Each student will have their own growth curves shaped by the raw mathematics scores they have achieved over three years. The model equations are as follows:

Level-1: $\quad \mathrm{Y}_{t i j}=\pi_{0 i j}+\pi_{l i j} *\left(G R A D E_{t i j}\right)+e_{t i j}$

Level-2: $\quad \pi_{0 i j}=\beta_{00 j}+r_{0 i j}$

$$
\pi_{1 i j}=\beta_{10 j}+r_{1 i j}
$$

Level-3: $\quad \beta_{00 j}=\gamma_{000}+u_{00 j}$

$$
\beta_{10 j}=\gamma_{100}+u_{10 j}
$$

$\pi_{l i j}$ : Coefficient indicating the rate of growth of the student-i during the specified academic year (2008-2009, 2009-2010 and 2010-2011 academic year) in school-j.

$G R A D E_{t i j}:$ Mathematical achievement of the student $i$ at $t$ time.

$\beta_{10 j}$ : Mean growth rates of students in school-j

$r_{l i j}$ : Second-level slope $\left(\beta_{10 j}\right)$ effect. The difference between the rate of mathematics score of student $i$ and the school $j$ 's average rate of mathematics score; the deviation amount. The mean is " 0 " and variance is $\tau_{\pi \text {. }}$

$\gamma_{100}$ : Mean of all students' growth rates in mathematical achievement

$u_{10 j}$ : Third level slope effect. That is, the difference between the growth curve of the average mathematical achievement of the school $\mathrm{j}$ and the growth curve of the general mathematical achievement is the amount of deviation. In other words, it is the unexplained difference in average growth rates of schools. The mean is " 0 " and the variance is $\tau_{\beta}$.

After unconditional model analysis, conditional models (second and third-level models) were applied in three-level hierarchical linear growth model analysis. 
Level-2 model: The level-2 model was used to answer the third research question. Second-level variables allow for differences between individuals and groups. This model contains the explanatory variables (second level variables) of the unexplained variance at the first level intercept and slope. The second level model equation is given below:

Level-1: $S B S_{t i j}=\pi_{0 i j}+\pi_{l i j} *\left(G R A D E_{t i j}\right)+e_{t i j}$

Level-2: $\quad \pi_{0 i j}=\beta_{00 j}+\beta_{01 j} *\left(A B S E N T E E I S M 6_{i j}\right)+\beta_{02 j} *\left(G P A 6_{i j} \overline{\overline{G P A 6} . i j}\right)+r_{0 i j}$

$$
\pi_{1 i j}=\beta_{10 j}
$$

Level-3: $\quad \beta_{00 j}=\gamma_{000}+u_{00 j}$

$$
\begin{aligned}
& \beta_{01 j}=\gamma_{010} \\
& \beta_{02 j}=\gamma_{020}+u_{02 j} \\
& \beta_{10 j}=\gamma_{100}
\end{aligned}
$$

$\left(\right.$ ABSENTEISM6 ${ }_{i j}$ ): Student-i's sixth-grade attendance in school-j (The number of days when the learner does not come to the school)

$\beta_{01 j}$ : ABSENTEEISM6 effect; effect of students' sixth-grade attendance on mathematical achievement at sixth grade in school-j

$\left(G P A 6_{i j^{-}} \overline{G P A 6 . i j}\right)$ : year-end mathematics sixth-grade point averages of student-i in school-j (display of centered around group average)

$\beta_{02 j}$ : GPA6 effect; effect of students' year-end mathematics sixth-grade point averages on mathematical achievement at sixth grade in school-j

$\gamma_{010}$ : Average effect of all of the students' sixth-grade attendance on mathematical achievement at sixth grade

The result of the level-1 analysis shows that the growth rates of the students are not statistically significant. For this reason, the $\pi_{l i j}$ coefficient was included as a fixed variable in the level-2 analysis. However, since the $\pi_{l i j}$ coefficient was included as a constant variable in the analysis, the residuals $r_{1 i j}$ and $u_{10 j}$ were not included in the model equation. At the second level, students' attendance in the sixth grade (ABSENTEEISM6) and year-end mathematics grade point averages (GPA6) were included. The significance of residuals of the variables has been examined before level-2 analysis. As a result of the study, it was decided that ABSENTEEISM6 variable should be included as a fixed constant and (GPA6) variable should be included as a random variable. Since ABSENTEEISM6 variable is fixed, the value $u_{01 j}$ is not included in model equality.

Level-3 model: This model was used to answer the fourth research question. Third level parameters describe the distributions of the average mathematical achievement and mathematical achievement curves as a function of school-level variables (school size and type). The third level model equation is as follows:

Level-1: $\mathrm{SBS}_{t i j}=\pi_{0 i j}+\pi_{l i j} *\left(G R A D E_{t i j}\right)+e_{t i j}$

Level-2: $\quad \pi_{0 i j}=\beta_{00 j}+r_{0 i j}$

$$
\pi_{1 i j}=\beta_{10 j}
$$

Level-3: $\quad \beta_{00 j}=\gamma_{000}+\gamma_{001}\left(T Y P E_{j}\right)+u_{00 j}$

$$
\beta_{10 j}=\gamma_{100}
$$

As in the level-2 model, since the $\pi_{l i j}$ coefficient was included as a fixed variable in the model, residual values of $r_{I i j}$ and $u_{10 j}$ were not included in the model equality. Here, other than the coefficients in the first and second level model equations, the coefficient $\gamma_{001}$ is explained.

$\gamma_{001}$ : Effect of school mean on the general mean. 
Reliability of HLM models: Assumptions were checked before starting HLM analysis. Assumptions of the three-level hierarchical linear development model are as follows: a) Metric; the dependent variable is measured over time on a general scale. b) The shape of the change is linear; change/growth increases with constant intervals. c) Distribution of errors by mean "0"; independent, normal distributions of errors with constant variance. d) Covariance structure; each variable is unrelated to its own level and another level of error (Raudenbush \& Bryk, 2002, p. 255). Meeting necessary assumptions prevents bias results in HLM analysis. In this study, all the variables meet the assumptions.

As a result of the completely unconditional model analysis, the reliability of level one $\left(\pi_{0}\right)$ and two $\left(\beta_{00}\right)$ intercept coefficients were estimated as 0.82 and 0.91 respectively. This can be interpreted based on the fact that the data included in the analysis were obtained with sufficient reliability for the estimation of the mathematics averages. In addition, the deviation value for this completely unconditional model was found as 83347.167906. Estimated number of parameters was 4 .

As a result of the first-level model analysis, the reliability coefficients for the intercept point $\left(\pi_{0}, \beta_{00}\right)$ were estimated as 0.40 and 0.82 , respectively. The reliability coefficients of slopes $\left(\pi_{1}, \beta_{10}\right)$ were estimated as 0.003 and 0.35 , respectively. Here, the low-reliability coefficients of the slopes are due to the slopes not being as constant as the intercept. Very low reliability in HLM analysis does not indicate that the HLM analysis is invalid. Low reliabilities indicate that the variable needs to be fixed in a top model because the variable has a really small variance, or the corresponding variances are hardly sampled (Raudenbush \& Bryk, 2002). Raudenbush and Bryk (2002) also stated that they could be regarded as reliable if their reliability values are above 0.05 .

In this study, the deviation value estimated for the completely unconditional model was found as 83347.167906 while the estimated deviation value for the level-1 growth model was found as 83341.505305. The estimated number of parameters is 9. It can be said that level-1 growth model did not fit well because the difference between the deviation values (5.66) is not more than twice the chisquare value (11.07), which is the difference between the estimated parameter numbers in the freedom degree models (5). As a result of the HLM growth model analysis, the inability to predict development supports this situation.

As a result of the analysis of the level-2 model, the reliability of the level-1 intercept coefficient was increased by 0.14 and estimated as 0.54 . The reliability of the second-order intercept coefficient was increased by 0.14 and estimated as 0.96 . In this study, the deviation value estimated for the completely unconditioned model was 83347.167906 while the estimated deviation value for the level-2 model was 79883.176924. The estimated number of parameters was 9. It can be said that the difference between the deviation values (3463.99) was better than that of the level-2 model. This is the case because the difference between the estimated number of parameters in the degree-offreedom models (5) was at least twice as large as the chi-square value (11.07).

As a result of the third level analysis, the reliability of the intercept coefficient was estimated as 0.82 for the level-1 and 0.85 for the level-2. The deviation value estimated for the completely unconditional model was 83347.167906 while the estimated deviation value for the level-2 model was 83325.874254 . The estimated number of parameters was 6 . The difference between the deviation values (21.29) was at least twice as high as the chi-square value (5.99), which was the difference between the estimated parameter numbers in the freedom rank models (2).

Finally, the real ranges of $95 \%$ of the true values of the constant effect coefficients were estimated. A formula $\pm 1,96 \sqrt{\tau_{\beta}}$ was used to estimate the $95 \%$ confidence interval of a true value of the coefficient (Raudenbush \& Bryk, 2002, p. 55). Estimated coefficients stand between the confidence intervals generated for the variables, which is another evidence for the reliability of estimates. 


\section{RESULTS}

Findings related to the first question: "Do sixth-grade students' SBS mathematical achievement vary students and schools? If yes, what percentage of variance accounted for at each level?"

For this question, a completely unconditional model was analyzed and the result of the analysis are reported in Table 1. Here, the intercept coefficient is interpreted as the mathematical achievement in the sixth grade of the student. When Table 1 is examined, it is seen that the general mean $\left(\gamma_{000}\right)$ is estimated as 32.65 with a standard error of about 0.70 . When a $95 \%$ confidence interval is created around the general mean, it is expected that the true value of the general mean will be within the range of 31.28 to $34.02\left(\% 95 \mathrm{CI}\left(\gamma_{000}\right)=32.65 \pm(1.96)(0.70)\right)$.

Table 1. Completely Unconditional Model Analysis Results

\begin{tabular}{lcccc}
\hline Fixed Effect & Coefficients & Standard error & $t$ & Approximate $d . f$ \\
\hline Intercept, $\pi_{0}$ & & & & \\
$\quad$ Intercept $2, \beta_{00}$ & & & \\
\multicolumn{1}{c}{ Intercept $3, \gamma_{000}$} & $32.65^{*}$ & 0.7 & 46.66 & 39 \\
\hline Random Effect & Standard Deviation & Variance components & $d . f$ & $\chi 2$ \\
\hline Intercept $1, r_{0}$ & $9.48^{*}$ & 89.92 & 3675 & 20920.02 \\
Level-1, $e$ & 7.58 & 57.49 & & \\
Intercept $1 /$ Intercept $2, u_{00}$ & $4.21^{*}$ & 17.75 & 39 & 559.55 \\
\hline${ }^{*} p<0.05$ & & & &
\end{tabular}

Furthermore, if 95\% confidence interval is formed around the general average, it is expected that $95 \%$ of the average mathematics raw scores of the students will be in the range of 14.07 to 51.23 ( $\gamma \widehat{0} 0=32.65+(1.96) \sqrt{89.92})$. Likewise, it is expected that $95 \%$ of the average mathematical achievements of the schools will be between 24.40 and 40.90 $\gamma \widehat{0} 0=32.65 \overline{+}(1.96) \sqrt{17.75})$.

As seen in Table 1, the estimated value of variability in inter-student level $(e)$ is 57.49 , the estimated value of variability in intra-student level, the variance of $\left(r_{0}\right)$ is 89.92 and the estimated value of variability in school level $\left(u_{00}\right)$ is 17.75 . It can be said that there are statistically significant differences in means of mathematical achievements of students and general means of mathematics scores of schools since the $p$-values of coefficients are smaller than 0.001 alpha level. Furthermore, this indicates that it is necessary to establish a three-level hierarchical linear growth model $(p<0.001$, $d . f=3675)$ and schools $(p<0.001 ; d . f=39)$. In addition, if the shared variance ratio in the upper levels is greater than 0.10 , the multi-level analysis is allowed to continue (Lee, 2000). The extent to which the levels explain the variance in the SBS mathematics scores is calculated by means of interclass correlation (ICC) (Raudenbush \& Bryk, 2002, p. 230):

Test (intra-student) level ICC: $\hat{p}=\frac{57.49}{57.49+89.92+17.75}=0.35$

Inter-student level ICC: $\hat{p}=\frac{89.92}{57.49+89.92+17.75}=0.54$

School level ICC: $\hat{p}=\frac{17.75}{57.49+89.92+17.75}=0.11$

By calculating the interclass correlation, it was seen that the majority of the variance in mathematical achievement (0.54) could be explained by the student level, then the test (intra-students) level and at least the school level. It can be stated that the variables that most affect the students' mathematical 
achievement are the characteristics related to them, the characteristics related to the tests and the characteristics related to the schools, respectively.

Findings related to the second question: "Is there any growth in students' SBS mathematics raw scores in middle school from 2009 to 2011?"

To answer this question, the first level model (unconditioned model for growth) was analyzed. Intercept and GRADE variables are included as random variables to the model. Since the SBS raw scores are taken with their equivalence to HLM analysis, the raw scores for mathematics range between 0 and 78. The level-1 (growth model) analysis results are given in Table 2. The growth rate of students' mathematical achievements is estimated as $\gamma_{100}=0.03$ over the course of time. In other words, the average growth rate of the students in each year shows an increase of 0.03 . The $p$ value of $\gamma_{100}$ coefficient is not statistically significant $(p>0.05 ; d . f=39)$, so the change in the students' mathematical achievements can be described as a small coefficient that can be explained by sampling error. In other words, it can be said that the inclination coefficient is not statistically significant because the students' development in mathematical achievement in the three educationtraining processes is too small to estimate the difference.

Table 2. Level-1 (Growth Model) Analysis Results

\begin{tabular}{|c|c|c|c|c|}
\hline Fixed Effect & Coefficients & Standard error & $t$ & Approximate $d . f$ \\
\hline \multicolumn{5}{|l|}{ Intercept $1, \pi_{0}$} \\
\hline \multicolumn{5}{|l|}{ Intercept $2, \beta_{00}$} \\
\hline Intercept $3, \gamma_{000}$ & $32.61 *$ & 0.69 & 47.08 & 39 \\
\hline \multicolumn{5}{|l|}{ GRADE slope, $\pi_{l}$} \\
\hline \multicolumn{5}{|l|}{ Intercept $2, \beta_{10}$} \\
\hline Intercept $3, \gamma_{100}$ & 0.03 & 0.12 & 0.22 & 39 \\
\hline Random Effect & Standard Derivation & Variance components & d. $f$ & $\chi^{2}$ \\
\hline Intercept $1, r_{0}$ & $9.38 *$ & 87.87 & 3675 & 5534.12 \\
\hline GRADE slope, $r_{l}$ & 0.28 & 0.08 & 3675 & 3035.41 \\
\hline Level-1, $e$ & 7.57 & 57.25 & & \\
\hline Intercept $1 /$ Intercept $2, u_{00}$ & $4.00 *$ & 16.03 & 39 & 281.71 \\
\hline GRADE/ Intercept $2, u_{10}$ & $0.44 *$ & 0.19 & 39 & 62.93 \\
\hline
\end{tabular}

Findings related to the third question: "Do sixth-grade students' SBS mathematical achievement vary student-level variables (Gender-GENDER, grade point average in 6th grade-GPA6 and attendance at school in 6th grade-ABSENTEEISM6)? If yes, what percentage of variance accounted for the student-level variables?"

When an exploratory analysis was performed before starting HLM analysis, it was seen that the most important variables were ABSENTEEISM6 and GPA6. For this reason, the second level model was analyzed by adding "ABSENTEEISM6 and GPA6" variables to answer this problem. The variables were added only to the intercept coefficient because the students' progress was not statistically significant. The significance of the residuals of variables in the analysis has been examined. As a result of the study, it was decided that the variable ABSENTEEISM6 should be taken as the model constant while the variable GPA6 should be taken as the random variable. Furthermore, GPA6 was centered on the group average and tried to avoid possible multiple-connection problems. Since the residual variance in the second level of the "GRADE" variable does not make statistical sense, this variable is kept constant at the second and third levels. Two different tables were created for more favorable reporting of fixed and random effects. 
The results of the level-2 fixed effects analysis are given in Table 3. When Table 3 is examined, it can be seen that the coefficient of change of the variable ABSENTEEISM6 $\left(\gamma_{010}\right)$ is estimated as 0.05 with a standard error of about 0.02 . When $95 \%$ confidence interval is established, the actual value of the variable ABSENTEEISM6 is expected to be in the range of -0.09 to $-0.01\left(\% 95 \mathrm{CI}\left(\gamma_{000}\right)\right.$ $=-0.05 \pm(1.96)(0.02))$. The $p$ value of the coefficient $\gamma_{010}$ was examined to determine whether the effect of the variable ABSENTEEISM6 on the general mean is different from zero. The $\mathrm{H}_{0}$ hypothesis was rejected because the $p$ value of the coefficient is statistically significant $(p<0.05 ; \mathrm{d}$. $\mathrm{f}$ $=3634$ ). In other words, the mathematical achievement of the student who goes to school regularly is 0.05 units more than the student who is absent from school in sixth grade.

Table 3. Level-2 Fixed Effect Analysis Results

\begin{tabular}{|c|c|c|c|c|c|}
\hline Fixed Effect & Coefficients & Standard error & $t$ & Approximate $d . f$. & Effect size \\
\hline \multicolumn{6}{|l|}{ Intercept $1, \pi_{0}$} \\
\hline \multicolumn{6}{|l|}{ Intercept $2, \beta_{00}$} \\
\hline Intercept $3, \gamma_{000}$ & $32.92 *$ & 0.73 & 45.17 & 39 & --- \\
\hline \multicolumn{6}{|l|}{ ABSENTEEISM, $\beta_{01}$} \\
\hline Intercept $3, \gamma_{010}$ & $-0.05^{*}$ & 0.02 & -2.27 & 3634 & -0.005 \\
\hline \multicolumn{6}{|l|}{ GPA6, $\beta_{02}$} \\
\hline Intercept $3, \gamma_{020}$ & $0.42 *$ & 0.02 & 27.18 & 39 & 0.04 \\
\hline \multicolumn{6}{|l|}{$\begin{array}{l}\text { GRADE slope, } \pi_{1} \\
\text { Intercept } 2, \beta_{10}\end{array}$} \\
\hline Intercept $3, \gamma_{100}$ & 0.006 & 0.09 & 0.07 & 7349 & --- \\
\hline
\end{tabular}

When Table 3 is examined, it is seen that the GPA6 coefficient $\left(\gamma_{020}\right)$ is estimated as -0.42 with a standard error of about 0.02 . When $95 \%$ confidence interval is established, the true value of GPA6 variable is expected to be in the range of 0.38 to $0.46\left(\% 95 \mathrm{CI}\left(\gamma_{000}\right)=0.42 \pm(1.96)(0.02)\right)$. To determine whether the effect of GPA6 variable on the general mean is different from zero, the $p$ value of $\gamma_{020}$ coefficient is examined. The $\mathrm{H} 0$ hypothesis was rejected because the $p$ value of the coefficient was statistically significant $(p<0.001$, d.f $=39)$. In other words, the mathematical achievement of a student who has high year-end mathematics grade point average is higher than that of a student who has low year-end mathematics grade point average in the sixth grade. It can be said that the common effect of GPA6 variable is reported here. In other words, this variable has different effects on students in different schools.

When random effects are examined in Table 1, it is seen that level-1 intercept variance $\left(r_{0}\right)$ is estimated as 89.92. When the level variables are added to the level-2 model, this variance is estimated as 22.78 (Table 4). With the proportion of the difference between the two variances to the variance in the growth model explained, the variance of student level by the student level variables was calculated. The student-level estimates of the ABSENTEEISM6 and GPA6 variables explained 0.75 of student-level variance. Given that the student-level explains 0.54 of the variance in mathematical achievement, these variables explain 0.41 of the variance in mathematical achievement. When the effect of sizes of the variables of GPA6 and BASARIORT6 were examined, it was observed that the effects on mathematical achievement were too small to be felt in daily life (Ferguson, 2009).

Table 4. Level-2 Random Effect Analysis Results

\begin{tabular}{lcccc}
\hline Random Effect & Standard Deviation & Variance components & $d . f$ & $\chi^{2}$ \\
\cline { 3 - 5 } Intercept $1, r_{0}$ & $4.77^{*}$ & 22.78 & 3634 & 7942.70 \\
Level-1, $e$ & 7.58 & 57.49 & & \\
Intercept1/ Intercept $2, u_{00}$ & $4.30^{*}$ & 18.48 & 39 & 1435.93 \\
Intercept $1 /$ GPA6, $u_{02}$ & $0.09^{*}$ & 0.008 & 39 & 218.86 \\
${ }^{*} p<0.05$ & & & &
\end{tabular}


To determine whether the variance of mean mathematical achievements of students is different from zero, the $p$ values of the coefficient $\left(r_{0}\right)$ are examined. The $\mathrm{H}_{0}$ hypothesis is rejected because the coefficient $p$ is less than 0.001 alpha. In other words, some of the variance in student-level mathematical achievement remained unexplained.

Findings related to the fourth question: "Do sixth-grade students' SBS mathematical achievement vary school-level variables (school size-SIZE and type-TYPE)? If yes, what percentage of variance accounted for the student-level variables?”

It was seen that the most important variable was TYPE when an explanatory analysis was performed before starting HLM analysis. For this reason, the third level model was analyzed by adding only the "TYPE" indicator to the third level in order to answer this problem. The variables were added only to the intercept coefficient because the students' progress was not statistically significant. Two different tables were created for more favorable reporting of fixed and random effects. The results of the level-3 fixed effects analysis are given in Table 5.

Table 5. Level-3 Fixed Effect Analysis Results

\begin{tabular}{lccccc}
\hline Fixed Effect & Coefficients & Standard error & $t$ & Approximate $d . f$. & Effect size \\
\hline Intercept $1, \pi_{0}$ & & & & & \\
$\quad$ Intercept $2, \beta_{00}$ & & & & & \\
$\quad$ Intercept $3, \gamma_{000}$ & $32.04^{*}$ & 0.62 & 51.80 & 38 & -- \\
$\quad$ TYPE, $\gamma_{001}$ & $13.45^{*}$ & 2.36 & 05.70 & 38 & 3.19 \\
GRADE slope, $\pi_{l}$ & & & & & \\
$\quad$ Intercept $2, \beta_{10}$ & & & & & \\
$\quad$ Intercept $3, \gamma_{100}$ & 0.006 & 0.12 & 0.05 & 7389 & -- \\
\hline$p<0.05$ & & &
\end{tabular}

When Table 5 is examined, the TYPE variable coefficient $\left(\gamma_{001}\right)$ is estimated as 13.45 with about 2.36 standard error. When the $95 \%$ confidence interval is established, the actual value of the TYPE variable is expected to be in the range of 8.82 to $18.08\left(\% 95 \mathrm{CI}\left(\gamma_{000}\right)=13.45 \pm(1.96)(2.36)\right)$. The $p$ value of $\gamma_{001}$ coefficient was examined to determine whether the effect of the TYPE variable on the general mean is different from zero. The $\mathrm{H}_{0}$ hypothesis was rejected because the $p$ value of the coefficient is statistically significant $(p<0.001, d . f=38)$. In other words, the mathematical achievement in the sixth grade of the student who is attending private school is 13.45 which is more than the attendance in the public school.

When the random effects are examined from Table 1, it is seen that the second level intercept variance $\left(u_{00}\right)$ is estimated as 17.75 . When the level variables are added to the third level model, this variance is estimated as 9.97, Table 6. With the proportion of the difference between the two variances to the variance in the growth model explained, the variance of school level by the school level variables was calculated. The TYPE variable explained 0.44 of the school-level variance. Given that the school level explains 0.11 of the variance in mathematical achievement, the TYPE variable accounts for 0.05 of the variance in the mathematical achievement. When the effect of the size of the TYPE variable was examined, it was observed that the variable had a large effect on size for the school level (Ferguson, 2009).

Table 6. Level-3 Random Effect Analysis Results

\begin{tabular}{lcccc}
\hline Random Effect & Standard Deviance & Variance components & $d . f$ & $\chi^{2}$ \\
\hline Intercept $2, r_{0}$ & $9.48^{*}$ & 89.89 & 3675 & 20920.04 \\
Level-1, $e$ & 7.58 & 57.49 & & \\
Intercept $1 /$ Intercept $2, u_{00}$ & $3.16^{*}$ & 9.97 & 38 & 414.31 \\
\hline$* p<0.05$ & & & &
\end{tabular}


The p-values of the $\left(u_{00}\right)$ coefficient have been examined to determine whether the variance of mean mathematical achievements of schools is different from zero. The $\mathrm{H}_{0}$ hypothesis is rejected because the coefficient $p$ is less than 0.001 alpha value. In other words, the variance in mathematical achievement at school level remained unexplained. To explain the remaining variance, the analysis should be repeated by adding different demographic variables to the model.

\section{DISCUSSION and CONCLUSION}

The aim of this study is to determine the effects of variables related with students (gender, year-end grade point, school attendance) and schools (type and size) on SBS mathematical achievement and its growth by three-level HLM growth model. It is believed that using the three-level HLM growth model will remove the bias of single-level analysis. Aside from this, this will also serve as an example in the Turkish literature of three-level hierarchical growth model applications. The variables examined in this study, composed of some data that are collected and stored as fixed by the MoNE for all schools in Turkey every year. In this study, the SBS test is applied only to middle school students and in those years the middle schools are three years, so a student has no more than three repeated measures. In addition, vertical scaling was not found to be suitable for the structure of the SBS scores obtained. For this reason, the equivalence of the scores has been established by applying an equal percentage method instead of vertical scaling. The equivalents of the scores were used in the analysis of the research. The research findings were discussed within the framework of these limitations.

For studies looking at the effects of student and school characteristics on mathematical achievement, it is expected that most of the variance in mathematical achievement will be explained by student characteristics (Odden, Borman \& Fermanich, 2009; Zvoch \& Stevens, 2003). In this study, it was observed that the majority of students' variance in the sixth grade of mathematical achievement was explained by student characteristics, followed by intra-student (test) characteristics and finally by school characteristics. This can be substantiated by the fact that the vast majority of the variables affecting mathematical achievements are student-level, or that student-level variables have a large influence on predicting students' mathematical achievement. Turhan, Şener and Gündüzalp (2017) examined 39 studies related to school effectiveness and found that schools had less impact on student achievement than other factors (students, parents). Similar findings were obtained in Akyüz (2014), Aydın (2015), Sevgi (2009), Tavşancıl and Yalçın (2015). In this respect, it can be said that the effects of these characteristics on the academic achievement of students need to be studied on a bigger scale. It is also seen that the variance ratio which can be explained by intra-student (test) characteristics is also high. However, this level of variance remains unexplained because the variables related to the tests were not included in the model in this study. In the later models, student and school level variables were included in the model in an attempt to explain the variance in mean mathematical achievement.

In this study, unlike many studies (Ai, 1999; Ding vd., 2010; Green, 1995; Huang, et al., 2009; Raymond, 2009; Shapley et al., 2011; Shay, 2000; Shim, 1995; Wu, 2004; Yang, 2000; Zhu, 1998; Zvoch \& Stevens, 2006) using a three-level linear growth model, the mathematical achievements growth of students could not be estimated. It is thought that the reason why any growth has not been observed in this study might be due to the correlation between the tests. The correlation coefficient between the tests in the studies involving equated test scores is expected to exceed 0.87 (Schneider \& Dorans, 1998 as cited in Dorans, 1999). However, the correlation coefficients between SBS scores belonging to students in this study vary between 0.62 and 0.72 . The low correlation between the test scores reduces the comparability of test scores (Schneider \& Dorans, 1998 as cited in Dorans, 1999). In this context, it can be said that the different designs of the tests (such as the fact that the tests given to the pupils according to years have different numbers of items and that there is no anchor item in the tests) according to the class levels negatively affect the comparability of SBS achievement scores at different grade levels. Another reason for the non-observation of growth may be related to the data structure. The data used in the study were mostly obtained in a rather cumulative manner. This prevented the modeling of the correspondence between the answers given to the items. By modeling the answer pattern, the equivalence between the tests becomes more 
sensitive (Kolen \& Brennan, 2014). By providing a more sensitive equivalent of the mathematics test scores at different grade levels with vertical scaling, it is thought that small differences in mathematical achievement of students can be modeled.

Similar to the study of Zvoch and Stevens (2006), in this study, it was seen that the majority of the variance in the mathematical achievements of the sixth graders could be explained by the studentlevel variables (0.54). For this reason, the desire is to add the demographic variables (genderGENDER, grade point average-GPA6 and attendance at school in sixth grade-ABSENTEEISM6) of the students, who are thought to influence the mathematical achievement, to the model. However, it had been decided to include only the variables of the students' "grade point average and attendance at school in sixth grade" in the explanatory analysis carried out before the HLM analysis. It is necessary to create learning experiences by using the time carefully and efficiently for the student's mathematical achievement growth in a middle school to occur and continue. A teaching activity in which the student does not exist during the time allocated for learning causes the learning experiences to be incomplete (Altınkurt, 2008; Fidan, 2004; Özbaş, 2010; Sulu Çavumirza, 2012). In this context, the mathematical achievements of the students with high absenteeism are expected to be lower. From this study, it was observed that the variable "absenteeism" influenced the students' mathematical achievements in parallel with this expectation. Similarly, in the study carried out by Yavuz and Atar (2016), it was observed that the attendance of the students in the school affected the students' academic achievement. Another variable handled at the second level is the average grade point in sixth grade. There is no knowledge about mathematics grade point averages provided by the same teacher within a school year. This ambiguity introduced limitations into the study and the discussion was made considering this limitation. There are studies in the literature that examine the effect of the average yearly grade on the future test achievement of students. For example, Cyrenne and Chan (2012) examined students' mathematical achievement using HLM on data obtained from 5136 students from 84 schools. Likewise, Finn, Gerber and Wang (2002) and Kim (2006) examined the effect of the students' grade point average on the examinations taken the following year. As a result of the investigations, the researchers determined that the students' yearly mathematics grade point average predicted the achievement in the next mathematics examination. In other words, it was seen that the yearly mathematics grade point average affected the achievement of the next mathematics exam. Similarly, in this study, it was determined that the average mathematics grade point in the sixth grade affected SBS mathematical achievement of the students.

In the school level (level-3) analysis, it was desirable to add both the school type (TYPE) and the size (SIZE) as the school variables in the model. However, it was decided that only the "TYPE" variable was included in the analysis by the explanatory analysis carried out prior to the HLM analysis. As a result of the school level analysis, it was determined that the school type affected the students' SBS mathematical achievements. Similar to this research finding, Kim (2006), who studied the effects of student and school variables on the eighth, tenth, and twelfth-grade mathematical achievements, observed the impact of school achievement on student achievement in these three grades. It was determined that the mathematical achievements of students attending non-government schools at every grade level were higher than those of other students. It is known that some of the non-government schools in Kim's (2006) study sample selected their students through the exam. Similarly, some private schools in Turkey also determine their students by examinations. The schools in the sample of this study (data) were obtained from the sample of Ankara of the MoNE with the request for random school selection. The names of the schools were given a different code for the researcher, for ethical considerations. For this reason, it is not known whether the private school in the study sample selected its students by a special examination. If the private school in the study sample is selected by the exam, it is expected that the SBS achievements of the students going to this school will be high. Another study examining the effect of school type on student achievement is Lee and Smith's (2001) study. Lee and Smith (2001) examined the mathematical achievement of students with low and high socio-economic status according to school types. At the end of their study, students with high socioeconomic status were found to have a high level of mathematical achievement in all school types while those with low socioeconomic status were 
influenced by the types of schools they attended. Finally, the studies carried out by Arslan, Satic1 and Kuru (2006) determined the effectiveness of the public and private primary schools through teachers' opinions. From the studies, they conclude that private schools, to a large extent, are more effective than public schools. Turhan et al., (2017), in their study of effective school studies, found that only four studies from 39 studies made a comparison between the effectiveness of public and private school. They concluded that this number was quite low. Researchers emphasized that there must be further research on this issue and stated that due to the low number of studies, a clear and emphatic judgment on school effectiveness could not be achieved.

\section{Suggestions}

In this study, it is concluded that the type of school that students attend and their absenteeism in their schools affect their mathematical achievement. There are many reasons for these variables to be effective on students' achievement. One reason for this may be that private schools provide students with an effective learning environment. To have an effective learning environment, the size of the class should be small, the physical characteristics of the class should be suitable for learning activities, and the teachers should be equipped with the necessary knowledge (Engin, Özen \& Bayoğlu, 2009; Özden, 2017). In this context, additional buildings or new schools can be built to reduce class size. The physical properties of the new classes constructed can be designed in a teachable way. Existing classes can be used in the most appropriate way for teaching activities as much as possible. Finally, the qualifications of the teachers can be determined at certain intervals and their problems can be solved with the necessary courses. In an effective and efficient learning environment, students do not get bored and they maintain their interest and desire for learning (Engin et al., 2009; Özden, 2017). Students who do not get bored, and who are persistent about their interest and desire in learning, are expected to spend more time in such environments. Taking this into account, effective learning environments can be prepared at schools to prevent student absenteeism. Another reason for student absenteeism may be that the students may not find the education in their schools sufficient to be able to succeed in SBS (Y1lmaz, 2011). For this reason, the students do not attend the schools by taking reports and they might continue their education taking private lessons or in some other ways in this process. It is necessary to change the perception that the education given in schools is not enough. To do so, effective learning environments can be created, the necessary tools for teaching can be provided, or the teachers' lack of pedagogical knowledge can be eliminated if necessary. In addition, student absenteeism can contribute a certain percentage to the placement score in the SBS.

In this study, unlike some studies carried out abroad, no change was observed in the mathematical achievements of the students. This may be due to the fact that there was no real growth in mathematical achievement or that the data were not appropriate for the growth analysis. The number of items and item difficulties in the SBS exams taken in different years can be shown as an indicator of the inappropriateness of the data. In this context, the tests that can provide equivalence should be planned, prepared and implemented. Including vertically scaled data in the HLM analysis may facilitate the observation of growth if the data is appropriate. In addition, within the scope of this study, the achievement scores of the students were obtained as the total number of true and false responses. Therefore, the response patterns of students were not modeled. It is thought that mathematical achievement growth can be observed by modeling the students' response patterns. Finally, there is a need for more studies investigating mathematical achievement growth.

The effects of the variables (attendance of students in school, the grade point average in mathematical achievement and school type) on mathematical achievement were examined. This analysis can be repeated by obtaining different variables (socio-economic status of the student, educational status of the family, frequency and duration of the mathematics course, opportunities of the school, climate, student/mathematics teacher ratio, etc.), and the effects of variables used in the study with new variables on mathematical achievement can be examined. Similarly, the academic achievement of students and their developmental achievements in other domains apart from mathematics can be examined with similar variables using a three-level hierarchical linear growth model. Finally, in causal-comparative design of this study, it was seen that the variables of "students' 
attendance to school, average mathematics achievement, and school type" were found to affect students' mathematical achievements. However, the lack of an experimental study in this study constitutes the limitation of this study. For this reason, experimental studies including these variables are needed to determine the real effects discussed in the research.

\section{REFERENCES}

Ai, X. (1999). Gender differences in growth in mathematics achievement: three-level longitudinal and multilevel analyses of individual, home, and school influences (Doctoral Dissertation). Available from ProOuest Dissertations and Theses database (UMI No. 9940503).

Agodini, R. \& Harris, B. (2016). How teacher and classroom characteristics moderate the effects of four elementary math curricula. The Elementary School Journal, 117(2), 216-236.

Akyüz, G. (2014). TIMSS 2011'de Öğrenci ve Okul Faktörlerinin Matematik Başarısına Etkisi. Eğitim ve Bilim, 39(172), 150-162.

Altınkurt, Y. (2008). Öğrenci devamsızlıklarının nedenleri ve devamsızlığın akademik başarıya olan etkisi. Dumlupınar Üniversitesi Sosyal Bilimler Dergisi, 20, 129-142.

Altun, A. (2007). Effects of student and school related factors on the mathematics achievement in Turkey at eight grade level (Yayınlanmamış yüksek lisans tezi). Orta Doğu Teknik Üniversitesi, Fen Bilimleri Enstitüsü, Ankara.

Arslan, H., Satıcı, A. ve Kuru, M. (2006). Devlet ve özel ilköğretim okullarının etkililiğinin araştırılması. Eğitim ve Bilim Dergisi, 31(42), 15-25.

Atar, B. (2010). Basit doğrusal regresyon analizi ile hiyerarşik doğrusal modeller analizinin karşılaştırılması. Eğitimde ve Psikolojide Ölçme ve Değerlendirme Dergisi, 1(2), 78-84.

Atar, H. Y. \& Atar, B. (2012). Türk eğitim reformunun öğrencilerin TIMSS 2007 fen başarılarına etkisinin incelenmesi. Kuram ve Uygulamada Eğitim Bilimleri, 12(4), 26-36.

Aydın, M. (2015). Öğrenci ve okul kaynakl faktörlerin TIMSS matematik başarısına etkisi (Doktora Tezi). Necmettin Erbakan Üniversitesi, Eğitim Bilimleri Enstitüsü, Konya.

Aztekin S. \& Yilmaz, H. B. (2014). The effects of human and material resources on students' math achievement in 45 countries. Problems of Education in the 21 st Century, 62, 8-20.

Bryk, A., \& Raudenbush, S. (1988). Toward a more appropriate conceptualization of research on school effects: A three-level hierarchical linear model. American Journal of Education, 97(1), 65-108.

Büyüköztürk, Ş., Çakmak, E. K., Akgün, Ö. E., Karadeniz, Ş. \& Demirel, F. (2008). Bilimsel araştırma yöntemleri (14. Bask1). Ankara: Pegem A Yayınc1lık.

Cyrenne, P. \& Chan, A. (2012). High school grades and university performance: A case study. Economics of Education Review, 31, 524- 542.

Çelik, İ. (2016). Ülke özelliklerinin TIMSS 2011 sekizinci sınıf matematik başarısına çok düzeyli etkileri (Yüksek lisans tezi). Gazi Üniversitesi, Eğitim Bilimleri Enstitüsü, Ankara.

Çokluk, Ö., Şekercioğlu, G. \& Büyüköztürk, Ş. (2012). Sosyal bilimler için çok değişkenli istatistik SPSS ve LISREL Uygulamaları (3. Bask1). Ankara: Pegem A Yayıncılık.

Demir, İ. \& Kılıç, S. (2010). Öğrencilerin matematik başarısına etkileyen faktörlerin PISA 2003 kullanılarak incelenmesi. Hacettepe Üniversitesi Ĕ̈itim Fakültesi Dergisi, 38, 44-54.

Ding, C. S., Song, K. \& Richardson, L. (2010). Do mathematical gender differences continue? A longitudinal study of gender difference and excellence in mathematics performance in the U.S. Educational Studies. A Journal of the American Educational Studies Association, 40(3), 279-295.

Dorans, N.J. (1999). Correspondence between ACT and SAT I Scores. College Board Research Report 99-1. NY: The College Board.

Engin, A. O., Özen, Ş. \& Bayoğlu, V. (2009). Öğrencilerin okul öğrenme başarılarını etkileyen bazı temel değişkenler. Sosyal Bilimler Enstitüsü Dergisi, 3, 125-156.

Ferguson, C. J. (2009). An effect size primer: A guide for clinicians and researchers. Professional Psychology: Research and Practice, 40(5), 532-538.

Fidan, F. (2004). Çalışan çocuk olgusuna sosyo-psikolojik bakış. Danişma Kurulu, 4(1), 30-49.

Finn, J. D., Gerber, S. B., \& Wang, M. C. (2002). Course offerings, course requirements, and course taking in mathematics. Journal of Curriculum and Supervision, 17, 336-366.

Green, J. H. (1995). Is there inequality of educational opportunity? A new look using longitudinal data and a hierarchical model (Doctoral Dissertation). Available from ProOuest Dissertations and Theses database (UMI No. 9621011).

Heck R. H. \& Thomas, S. L. (2009). An introduction to multilevel modeling techniques (2. Ed.). New York: Routledge. 
Hox, J.J. (2010). Multilevel analysis: techniques and applications (2. Ed.). Great Britain: Routledge.

Huang, D., Leon, S., La Torre, D. \& Mostafavi, S. (2008). Examining the relationship between LA's best program attendance and academic achievement of LA's best students. National Center for Research on Evaluation, Standards, and Student Testing (CRESST) Report 749, University of California, Los Angeles.

İş Güzel, Ç. (2006). Uluslararası Öğrenci Değerlendirme Programında (PISA 2003) insan ve fiziksel kaynakların ögrencilerin matematik okuryazarlı̆̆ına olan etkisinin kültürler arası karşılaştırılması (Doktora tezi). Orta Doğu Teknik Üniversitesi, Fen Bilimleri Enstitüsü, Ankara.

Karabay, E. (2012). Sosyo-kültürel değişkenlerin PISA fen okuryazarlı̆̆ını yordama gücünün yıllara göre incelenmesi (Yüksek lisans tezi). Ankara Üniversitesi Eğitim Bilimleri Enstitüsü, Ankara.

Kao, Y., Davenport, J., Matlen, B., Thomas, L., \& Schneider, A. (2017). Bridging research and practice: Efficacy of a research-based redesign of a grade 7 mathematics curriculum. Paper presented at the Annual Meeting of the American Educational Research Association, San Antonio, TX.

Kolen, M. J. \& Brennan, R. L. (2014). Test equating, scaling, and linking methods and practices. USA: Springer.

Lee, V. E. \& Smith, J. B. (2001). Restructuring high schools for equity and excellence: What works. New York: Teachers College.

Lee, V. E. (2000). Using hierarchical linear modeling to study social contexts: The case of school effects. Educational Psychologist, 35 (2), 125-141.

Milli Eğitim Bakanlığı (2011). Ortaöğretim Kurumlarına Geçiş Sistemi - Seviye Belirleme Sınavı e-Başvuru Kılavuzu. Erişim adresi: http://www.meb.gov.tr

Odden, A., Borman, G. \& Fermanich, M., (2009). Assessing teacher, classroom, and school effects, including fiscal effects. Peabody Journal of Education, 79(4), 4-32.

Ötken, Ş. (2012). İlköğretim 7. sınıf SBS başarısını yordayan değişkenlerin belirlenmesi (Yüksek lisans tezi). Hacettepe Üniversitesi, Sosyal Bilimler Enstitüsü, Ankara.

Özbaş, M. (2010). İlköğretim okullarında öğrenci devamsızlığının nedenleri. Eğitim ve Bilim, 35(156), 32-44.

Özdemir, F. (2010). PISA 2003'de genel lise ögrencileri ve Kanuni Lisesi ögrencilerinin matematik başarısını etkileyen faktörlerin incelenmesi (Yüksek lisans tezi). Hacettepe Üniversitesi, Sosyal Bilimler Enstitüsü, Ankara.

Özden, Y. (2017). Sınıf içinde öğrenme öğretme ortamının düzenlenmesi. Emin Karip (Ed.), Sınıf yönetimi içinde (s. 36-69). Ankara: Pegem Akademi Yayıncılık.

Raudenbush, S.W. \& Bryk, A.S. (2002). Hierarchical linear models (2. Ed.). Newbury Park, CA: Sage

Raymond, K. J., (2009). Sensitivity of HLM growth and school effect estimates to the number of waves of data utilized (Doctoral Dissertation). Available from ProOuest Dissertations and Theses database (UMI No. $3410501)$.

Reçber, Ş. (2011). An investigation of the relationship among the seventh grade students' mathematics selfefficacy, mathematics anxiety, attitudes towards mathematics and mathematics achievement regarding gender and school type (Yüksek lisans tezi). Orta Doğu Teknik Üniversitesi Fen Bilimleri Enstitüsü, Ankara.

Savaşçı, H. S. (2011). Sosyoekonomik değişkenlerin ve okulun eğitim kaynaklarının ilköğretim 7. Sınıf ögrencilerinin akademik başarı düzeyleri ile ilişki durumu (Yüksek lisans tezi). Mehmet Akif Ersoy Üniversitesi, Sosyal Bilimler Enstitüsü, Burdur.

Schneider, D. \& Dorans, N. (1999). Research notes: Concordance between SAT ${ }^{\circledR} I$ and ACT ${ }^{\mathrm{TM}}$ scores for individual students. Office of Research and Development, College Entrance Examination Board: New York.

Sevgi, S. (2009). Türkiye'de okul ve öğrenci özelliklerinin matematik başarısı ile ilişkileri (Yüksek lisans tezi). Orta Doğu Teknik Üniversitesi, Fen Bilimleri Enstitüsü, Ankara.

Shapley, K., Sheehan, D., Maloney, C. \& Caranikas-Walker, F., (2011). Effects of technology immersion on middle school students' learning opportunities and achievement. The Journal of Educational Research, 104(5), 299-315.

Shay, S. A. E. (2000). A longitudinal study of achievement outcomes in a privatized public school: a growth curve analysis (Doctoral Dissertation). Available from ProOuest Dissertations and Theses database (UMI No. 9972554).

Shim, M. K. (1995). A longitudinal model for the study of equity issues in mathematics education (Doctoral Dissertation). Available from ProOuest Dissertations and Theses database (UMI No. 9543721).

Sulu Çavumirza, E. (2012). İlköğretim 8. sınıf öğrencilerinin sahip oldukları bazı değişkenler ve algıladıkları okul iklimi bakımından seviye belirleme sınavında aldıkları puanların değerlendirilmesi (Yüksek lisans tezi). Necmettin Erbakan Üniversitesi, Eğitim Bilimleri Enstitüsü, Konya.

ISSN: 1309 - 6575 Eğitimde ve Psikolojide Ölçme ve Değerlendirme Dergisi

Journal of Measurement and Evaluation in Education and Psychology 
Tan, C. Y. \& Hew, K. F. (2018). The impact of digital divides on student mathematics achievement in confucian heritage cultures: A critical examination using PISA 2012 data. International Journal of Science and Mathematics Education, 16, 1-20. Available from https://doi.org/10.1007/s10763-0189917-8

Tavşancıl E. \& Yalçın, S. (2015) A Determination of Turkish Student's Achievement Using Hierarchical Linear Models in Trends in International Mathematics-Science Study (TIMSS) 2011. The Anthropologist, 22(2), 390-396.

Turhan, M., Şener, G., \& Gündüzalp, S. (2017). Türkiye'de Okul Etkililiği Araştırmalarına Genel Bir Bakıș. Turkish Journal of Educational Studies, 4(2). 103-151.

Wu, C. (2004). The educational aspirations and high school students' academic growth: A hierarchical linear growth model (Doctoral Dissertation). Available from ProOuest Dissertations and Theses database (UMI No. 3145778).

Yang, J. (2000). The effects of school community on students' academic learning growth: A multilevel analysis of nels: 88 for high schools (Doctoral Dissertation). Available from ProOuest Dissertations and Theses database (UMI No. 9972937).

Yavuz, E. \& Atar, H. Y. (2016). Examining the effects of students and school variables on PISA 2012 problemsolving achievement in Turkey. New Trends and Issues Proceedings on Humanities and Social Sciences, 05, 24-30.

Yılmaz, Ç. (2011). Öğrenci devamsızlıklarının nedenleri. Ĕğitişim Dergisi, 29. Erişim adresi: http://www.egitisim.gen.tr/tr/index.php/arsiv/21-30/sayi-29-cesitleme-ocak-2011/830-ogrencidevamsizliginin-nedenleri

Yılmaz, E. T. (2006). Uluslararası öğrenci başarı değerlendirme programı (PISA)'nın Türkiye'deki ögrencilerin matematik başarlarını etkileyen faktörler (Yüksek lisans tezi). Hacettepe Üniversitesi, Sosyal Bilimler Enstitüsü, Ankara.

Yi, P. \& Shin, I. (2018). Mult1level relations between external accountability, internal accountability, and math achievement: A cross-country analysis. Problems of Education in The 21st Century, 76(3), 318-332.

Zhu, R. (1998). Application of hierarchical linear model (3L) to the study of student and school effects on elementary student' math performance over time (Doctoral Dissertation). Available from ProOuest Dissertations and Theses database (UMI No. 9919001).

Zvoch, K. \& Stevens, J. J. (2006). Successive student cohorts and longitudinal growth models: An investigation of elementary school mathematics performance. Education Policy Analysis Archives, $14(2), 1068-2341$.

\section{Öğrenci ve Okul Değişkenlerinin Matematik Başarısı ve Gelişimine Etkileri}

\section{Giriş}

Öğrencilerin matematik alanında akademik başarılarının gelişmesinde okulların önemli bir işlevinin olması beklenir. Bu bağlamda küçük yaşlardan itibaren üstelik zorunlu olarak verilen eğitim hizmetinin yürütüldüğü okullar, sıkça araştırma konusu olmuştur. Ayrıca okullar, aile dışındaki sosyal ortamlar olarak öğrenmenin en çok gerçekleştiği yerler olması bakımından dikkate değerdir. Böylece birey için okul hayatına başlamak önemli bir dönüm noktası olarak kabul edilebilmektedir.

$\mathrm{Bu}$ çalışmanın amacı, öğrenci (cinsiyet, yılsonu başarı ortalaması, okula devam durumu) ve okul (türü ve büyüklüğü) değişkenlerinin ortaokulda matematik başarısı ve gelişimine etkilerini belirlemektir. Çalışmadaki gelişim, öğrencilerin yıllar içinde aldıkları SBS matematik puanlarındaki değişimi ifade etmektedir. Veri yapısı çok düzeyli olduğundan bu çalışmada tek düzeyli analiz yöntemlerinin yanlılığını önlemek için üç seviyeli hiyerarşik lineer gelişim modeli kullanılmıştır. Modelde düzey-1, öğrencilerin SBS matematik puanlarının tekrarlı ölçümlerinden, düzey-2 öğrencilere ait değişkenlerden ve son olarak düzey-3 okullara ait değişkenlerden oluşmaktadır.

Türkiye'deki alan yazın incelendiğinde matematik başarısını ve matematik başarısındaki gelişimi etkileyen faktörleri lineer gelişim modeliyle inceleyen bir çalışmaya rastlanmamıştır. Bununla 
birlikte yurt dışında üç düzeyli hiyerarşik lineer gelişim modellerinin kullanıldığı pek çok çalışma mevcuttur (Ding, Song ve Richardson, 2010; Huang, Leon, La Torre ve Mostafavi, 2009; Raymond, 2009; Shapley, Sheehan, Maloney ve Caranikas-Walker, 2011; Shim, 1995; Wu, 2004; Yang, 2000; Zhu, 1998). Ayrıca ilgili alan yazın incelendiğinde yurt dışında matematik başarısına etki eden öğrenci, okul ve ülke değişkenlerini üç düzeyli hiyerarşik lineer model (HLM) ile inceleyen bir çok çalışma (Agodini ve Harris, 2016; Kao, Davenport, Matlen, Thomas ve Schneider, 2017; Tan ve Hew, 2018; Yi ve Shin, 2018) bulunurken Türkiye'de yalnızca iki çalışmaya (Aztekin ve Yılmaz, 2014; Çelik, 2016) ulaşılmıştır. Çelik (2016) çalışmasında sadece ülke değişkenlerinin etkilerini ele alırken, Aztekin ve Yılmaz'ın (2014) çalışmalarında öğrenci, okul ve ülkelere ait değişken etkilerini incelemişlerdir. Ayrıca bu çalışmalarda PISA ve TIMSS matematik başarısındaki bazı değişkenlerin etkileri incelenmiş̧ir. PISA ve TIMSS gibi sınavlar uluslararası komitelerin amaç ve hedeflerini yansitırken, SBS uluslararası sınavlardan farklı olarak, Türk eğitim sisteminin amaç ve hedeflerini yansıtmaktadır. Bu çalışmanın, öğrencilerin SBS matematik alt testinde yıllar içerisindeki başarı değişimleri ve bazı öğrenci ve okul değişkenlerinin SBS matematik başarılarına etkilerinin incelemesi açısından önemli olduğu düşünülmektedir. Türkiye'de yapılan çalışmalar incelendiğinde cinsiyet, okula devam durumu, öğretmen nitelikleri gibi değişkenlerin matematik başarısına olan etkilerinin çoğunlukla tek ya da iki düzeyli modellerle incelendiği görülmüştür. Türk alan yazınında çok düzeyli verilerin analizinde üç düzeyli modellerin kullanımına artan bir ilgi gözükse de, geçerli sonuçlar elde etmek için hala çok azdır (Çelik, 2016). Tek düzeyli analiz yöntemlerinin yanlılığından kaçınmak ve alan yazındaki üç düzeyli hiyerarşik lineer gelişim modeli uygulamalarının eksikliğinin giderilmesi için bu çalışmada üç düzeyli hiyerarşik lineer gelişim modeli kullanılmıştır. Bu şekilde ögrenci ve okul değişkenlerinin matematik başarısına etkilerinin incelenmesinin yanı sıra matematik başarısındaki gelişimin de incelenmesi hedeflenmiştir.

\section{Yöntem}

Öğrencilerin matematik başarıları ve matematik başarılarındaki gelişimi etkileyen öğrenci ve okul değişkenleri incelendiği için bu çalışma nedensel karşılaştırma modelindedir. Araştırma evrenini, Ankara ilinde 2008 yılında ortaokula başlayıp 2011 yılında ortaokuldan mezun olan ortaokul öğrencileri oluşturmaktadır. Örneklem için seçkisiz olmayan, tipik durum örnekleme yöntemi kullanılmıştır. Araştırma örneklemini, Ankara ilindeki 40 ortaokuldan, 2008 yılında ortaokula başlayıp 2011 yılında mezun olmuş, 3715 öğrenci oluşturmaktadır. Öğrencilerin üç yıllık eğitimöğretim sürecini aynı okulda geçirmeleri dikkate alınmıştır. Çalışmada kullanılan veriler Milli Eğitim Bakanlığı ile yapılan yazışmalar sonucu elde edilmiştir. Bu nedenle çalışmada incelenen değişkenler, her yıl MEB tarafından Türkiye'deki bütün okullar için sabit olarak toplanıp saklanan bazı verilerden oluşmaktadır. Öğrencilerin ilgili eğitim-öğretim dönemlerinde uygulanan SBS matematik alt testi ham puanları bağımlı değişken olarak analize dahil edilmiştir. "Cinsiyet, altıncı sınıftaki yılsonu matematik not ortalaması ve altıncı sınıftaki okula devam durumu" öğrenci düzeyi değişkenlerini oluştururken "okul türü ve büyüklüğü” okul düzeyi değişkenlerini oluşturmaktadır.

Değişkenlerin etkilerinin incelenebilmesi için verilerin analizinde üç düzeyli hiyerarşik lineer gelişim modeli kullanılmıştır. Öğrencilerin SBS matematik alt testi ham puanları, eşit yüzdelikli eşitleme çalışması yapıldıktan sonra üç düzeyli hiyerarşik lineer gelişim modeline dahil edilmiştir.

\section{Sonuç ve Tartışma}

$\mathrm{Bu}$ çalışmada, öğrenci (cinsiyet, yılsonu not ortalaması, okula devam durumu) ve okul (türü ve büyüklüğ̈̈) değişkenlerinin öğrencilerin SBS matematik başarısı ve gelişimine etkilerini üç düzeyli HLM gelişim modeliyle belirlemek amaçlanmıştır. Çalışmada, SBS sınavi sadece ortaokul öğrencilerine uygulandığı ve o y1llarda ortaokul üç yıl olduğu için bir öğrenci en fazla üç tekrarlı ölçüme sahiptir. Ayrıca çalışmada, elde edilen SBS puanlarının yapısına uygun dikey ölçekleme yöntemi (vertical scaling) bulunamamıştır. Bu nedenle dikey ölçekleme yerine eşit yüzdelikli yöntem uygulanarak puanların eşdeğerleri oluşturulmuştur. Araştırmanın analizinde puanların eşdeğerleri kullanılmıştır. Araştırma bulguları bu sınırlılıklar çerçevesinde tartışılmıştır. 
Okul ve öğrenci özelliklerinin matematik başarısına etkilerinin incelendiği çalışmalarda, matematik başarısındaki varyansın büyük bir kısmının öğrenci özellikleri tarafından açıklanması beklenir (Odden, Borman ve Fermanich, 2009; Zvoch ve Stevens, 2006). Bu çalışmada, öğrencilerin altıncı sınıftaki matematik başarılarındaki varyansın büyük çoğunluğunun öğrenci özellikleri, sonra öğrenciler-içi (test) özellikleri en son olarak da okul özellikleri tarafından açıklanabileceği görülmüştür. Bu durum matematik başarılarını etkileyen değişkenlerin büyük çoğunluğunun öğrenci düzeyinde olduğu veya öğrenci düzeyi değişkenlerin öğrencilerin matematik başarılarını yordama da büyük öneme sahip olduğu şeklinde ifade edilebilir. Turhan, Şener ve Gündüzalp (2017), okul etkililiği ile ilgili 39 çalışmayı çeşitli yönleriyle incelemişler ve okulların diğer faktörlere (öğrenci, veli) göre öğrenci başarıları üzerinde daha az etkileri olduğu bulgusuna ulaşmışlardır. Benzer bulgunun Akyüz (2014), Aydın (2015), Sevgi (2009), Tavşancıl ve Yalçın'ın (2015) çalışmalarında da elde edildiği görülmüsstür. Bu doğrultuda öğrenci özellikleri ile bu özelliklerin öğrencilerin akademik başarılarına etkisinin daha çok çalışılmaya ihtiyaç duyulduğu söylenebilir. Ayrıca test özellikleri tarafından açıklanabilecek varyans oranının da yüksek olduğu görülmektedir. Fakat bu çalışmada testler ile ilgili değişkenler modele dahil edilmediği için bu düzey varyansı açıklanmadan kalmıştır. Sonraki modellerde öğrenci ve okul düzeyi yordayıcıları modele dahil edilerek ortalama matematik başarısındaki varyans açıklanmaya çalışılmıştır.

$\mathrm{Bu}$ çalışmada, üç düzeyli lineer gelişim modeli kullanılan birçok çalışmanın aksine öğrencilerin matematik başarılarındaki gelişim gözlenememiştir. Gelişimin gözlenememesinin bir nedeni testler arasındaki korelasyonun olabileceği düşünülmektedir. Eşitleme çalışmalarında testler arasındaki korelasyon katsayısının 0.87'yi geçmesi istenir (Dorans 1998'den akt. Schneider ve Dorans, 1999). $\mathrm{Bu}$ çalışmada öğrencilere ait SBS puanları arasındaki korelasyon katsayıları 0.62 ile 0.72 aralığında değişmektedir. Test puanları arasındaki korelasyonun düşük olması test puanlarının karşılaştırılabilirliğini olumsuz etkilemektedir (Dorans 1998'den akt Schneider ve Dorans, 1999). Bu bağlamda testlerin sınıf düzeylerine göre farklı dizayn edilmeleri (yıllara göre öğrencilere verilen testlerin farklı sayıda maddeye sahip olmaları ve testlerde ortak maddenin bulunmaması gibi) de farklı sınıf düzeylerindeki SBS başarı puanlarının karşılaştııılabilirliklerini olumsuz etkilediği söylenebilir. Gelişimin gözlenememesinin bir diğer nedeni de veri yapısı olabilir. Çalışmada kullanılan veriler soru bazından ziyade kümülatif olarak elde edilmiştir. Bu durum maddelere verilen cevaplar arasındaki örüntünün modellenmesini engellemiştir. Cevap örüntüsünün modellenmesiyle testler arasındaki eşitleme çalışması daha duyarlı olmaktadır (Kolen ve Brennan, 2014). Dikey ölçeklemeyle farklı sınıf düzeylerindeki matematik test puanlarının daha duyarlı bir eşdeğerliğin sağlanmasıyla öğrencilerin matematik başarılarındaki küçük değişimlerin modellenebileceği düşünülmektedir.

Ortaokulda bir öğrencinin matematik başarısı gelişiminin oluşması ve devam etmesi için zamanın dikkatli ve verimli kullanılarak öğrenme yaşantılarının oluşturulması gerekmektedir. Öğrenme için ayrılan süre içerisinde öğrencinin bulunmadığı bir öğretim etkinliği, onun gerçekleştireceği öğrenme yaşantılarının eksik olmasına neden olmaktadır (Altınkurt, 2008; Fidan, 2004; Özbaş, 2010; Sulu Çavumirza, 2012). Bu bağlamda devamsızlığı fazla olan öğrencilerin matematik başarılarının daha düşük olması beklenir. Bu çalışmada, bu beklentiyle paralel olarak "devamsızlık" değişkeninin öğrencilerin matematik başarılarını etkilediği belirlenmiştir. Benzer şekilde Yavuz ve Atar'ın (2016) çalışmasında öğrencilerin okula devam durumlarının, öğrencilerin akademik başarılarını etkiledikleri görülmüştür. Düzey 2'de ele alınan bir diğer değişken altıncı sınıf yılsonu başarı ortalamalarıdır. Alan yazında yılsonu başarı ortalamalarının öğrencilerin gelecekteki sınav başarılarına etkisini inceleyen çalışmalar mevcuttur. Örneğin Cyrenne ve Chan (2012), 84 okuldan 5136 öğrenciden elde ettiği veriler üzerinde HLM kullanarak öğrencilerin matematik başarısını incelemiştir. Benzer şekilde Finn, Gerber ve Wang (2002) ve Kim (2006) de öğrencilerin yılsonu başarı ortalamalarının bir sonraki yıl girdikleri sınavlara etkilerini incelemişlerdir. Araştırmacılar incelemeleri sonucunda, öğrencilerin yılsonu matematik başarı ortalamaları ile bir sonraki matematik sınavı başarılarının yordandığını tespit etmişlerdir. Başka bir ifade ile yılsonu matematik başarı ortalamasının bir sonraki matematik sınavı başarısını etkilediği görülmüştür. Benzer şekilde, bu çalışmada da yılsonu 
matematik başarı ortalamasının öğrencilerin altıncı sınıf SBS matematik başarılarını etkilediği belirlenmiştir.

Okul düzeyinin analizi sonucunda, okul türünün öğrencilerin SBS matematik başarılarını etkilediği belirlenmiştir. $\mathrm{Bu}$ araştırma bulgusuna benzer şekilde okul ve öğrenci değişkenlerinin sekizinci, onuncu ve 12.sınıf matematik başarıları üzerindeki etkisini araştıran Kim'in (2006) çalışmasında okul türünün her üç sınıfta öğrenci başarısı üzerindeki etkisini gözlemlemiştir. Her sınıf düzeyinde de devlet okulu olmayan okullarda öğrenimine devam eden öğrencilerin matematik başarılarının diğer öğrencilere göre yüksek olduğu belirlenmiştir. Kim'in (2006) çalışma örnekleminde bulunan, devlet okulu olmayan bazı okulların öğrencilerini sınav ile seçtikleri bilinmektedir. Benzer şekilde Türkiye'de de bazı özel okullar kendi öğrencilerini sınav ile belirlemektedirler. Bu çalışmanın örnekleminde bulunan okullara (verilere) MEB'in Ankara örnekleminden randum okul seçme talebi ile ulaşılmıştır. Ulaşılan okulların isimleri etik ilkeleri gözetilerek araştırmacılara farklı bir kodlama ile verilmiştir. Bu nedenle çalışma örneklemindeki özel okulların öğrencilerini özel bir sınavla seçip seçmedikleri bilinmemektedir. Eğer çalışma örnekleminde bulunan özel okul öğrencilerini sınav ile seçti ise, bu okula giden öğrencilerin SBS başarılarının yükssek olması beklenilen bir sonuçtur. Okul türünün öğrenci başarısına etkisini inceleyen bir diğer çalışma Lee ve Smith'e (2001) aittir. Lee ve Smith (2001), düşük ve yüksek sosyo-ekonomik statüye sahip öğrencilerin okul türlerine göre matematik başarılarını incelemiş̧lerdir. Çalışmalarının sonunda yüksek sosyo-ekonomik statüye sahip öğrencilerin her türlü okulda öğrenmelerinin ve bu doğrultuda matematik başarılarının yüksek olduğunu belirlerken, düşük sosyo-ekonomik statüye sahip öğrencilerin devam ettikleri okulların türlerinden etkilendiklerini belirlemişlerdir. Son olarak devlet ve özel ilköğretim okullarının etkililiğini öğretmen görüşleriyle belirlemek isteyen Arslan, Satıcı ve Kuru'nun (2006) çalışmaları sonucunda, belirlenen boyutlarda özel okulların devlet okullarından daha etkili oldukları belirlenmiştir. Etkili okul çalışmalarının incelendiği çalışmada Turhan, Şener ve Gündüzalp (2017), 39 çalışmanın içerisinden sadece dört çalışmanın devlet ve özel okul etkililiği karşılaştırmasında bulunduğunu ve bu sayının oldukça az olduğunu belirtmişlerdir. Araştırmacılar bu konuda daha fazla araştırma yapılmasını vurgularken az çalışmanın yapılmasından dolayı okul etkililiği konusunda net bir yargıya ulaşılamayacağını belirtmişlerdir.

Sonuç olarak, üç düzeyli hiyerarşik lineer gelişim modeli analizi sonucunda öğrencilerin matematik başarılarında bir gelişme olmadığı ancak, "altıncı sınıfta okula devam durumu, yılsonu matematik not ortalamasının ve okul türünün" öğrencilerin altıncı sınıftaki matematik başarılarını istatistiksel olarak etkiledikleri görülmüştür. Araştırmada deneysel bir çalışmanın yapılmaması bu çalışmanın bir sınırlılığını oluşturmaktadır. Bu nedenle etkili bulunan değişkenlerin, etkilerinin tam olarak belirlenebilmesi için bu değişkenleri içeren deneysel çalışmalara ihtiyaç duyulmaktadır. 